\title{
Start Lost Mutation
}

National Cancer Institute

\section{Source}

National Cancer Institute. Start Lost Mutation. NCI Thesaurus. Code C148649.

A mutation occurring within the start codon of a gene that results in a sequence that no longer encodes a start codon. This can result in a gene deletion or gene transcription may start from an alternative start site. 